\title{
Queen Saint Margaret, Jesuit Devotion, and Seventeenth-Century Scottish Catholicism
}

\author{
Mary Elizabeth Horan \\ Independent Scholar \\ maryelizhoran@gmail.com
}

\begin{abstract}
From one small devotional book about Queen Saint Margaret and its three translations we can learn much about the nature of post-Reformation, seventeenth-century Scottish Catholicism. First, the style of the book's meditation informs us of the influential role that the Jesuits played in forming the next generation of Scottish men and priests, as well as shaping the intellectual and devotional culture of post-Reformation Scottish Catholicism. Second, this book was part of a larger movement of writings and devotional practices designed to emphasize the "Scottishness" of Catholics' faith while in exile among other Western European traditions. Third, the paratextual elements provide evidence that the Scots colleges were closely aligned with the royalist cause. And finally, this book and others like it were used to solicit aid and support for the Scots colleges.
\end{abstract}

\section{Keywords}

Counter-Reformation - devotion - seventeenth century - Catholicism - faith in exile saints and cults - Jesuits - St. Margaret of Scotland - Scots colleges - Scottish identity

\section{Introduction}

In honor of King Charles II's (166o-85) restoration in 166o, the Jesuits at the Scots College in Douai published a devotional book entitled L'Idée d'une reine parfaite (The idea of a perfect queen). The original French text is a consolidated translation of the Latin Vita composed by Turgot of Durham (c.1050-115), Margaret's confessor and spiritual guide, shortly after her death. The reine parfaite,

(C) MARY ELIZABETH HORAN, 2020 | DOI:10.1163/22141332-00701006

This is an open access article distributed under the terms of the prevailing CC-BY-NC-ND 4.0 license. 
or perfect queen, was Queen Saint Margaret of Scotland (c.1045-93), and the Jesuits used the opportunity of this small publication to support Charles's claim to the English throne by tracing his lineage back to Margaret, King Malcolm III's (1058-93) undisputed queen consort. This short work struck a chord in the Scottish Catholic community as it was translated into English in 1661, Italian in 1675 , and finally into Spanish in $1679 .{ }^{1}$

Whereas Turgot's Vita was written for posterity's sake, the Jesuits' derivative work was composed primarily with a devotional purpose in mind. To that end, the author gives his readers a chronological review of Margaret's life and reign with an aim to direct them to imitate Margaret's pious behaviors. The author weaves in didactic addresses to the readers, which are set off from the regular flow of narration with italics and are found at regular intervals throughout the text, both in the main body and in the two eclogues about David (1124-53) and Matilda (1100-18), two of Margaret's pious children, that follow. Female readers are the intended audience for the original French work as is evidenced by its preface- -Aux Dames"-but specifically royal women or those associated with the court whose experience was similar enough to Margaret's.

Although its ultimate reach or readership is unknown, this devotional book - with its three translations-is worthy of attention. While there was very little devotional material written by Scots for a Scottish audience, and even less that survived the post-Reformation penal laws, this work substantiates that there was at least an effort by exiled Scottish Catholic communities to fill that need. One way a book like this survived was in the hands of missionary priests, like Robert Strachan, who, in 1695, left his mark of ownership in a 1675 duodecimo, Italian edition of the work, now in the Blairs Library Collection, housed in Aberdeen University Library. The other way that books like this survived was in the library collections of exiled Scottish Catholic institutions, such as the Scots colleges. The exact provenance of the 1679 Spanish edition (referenced later), now part of the library of The Royal Scots College Salamanca, is unknown. It was likely part of the library of the Madrid Scots college since its translator was a professor there. Although the provenance of the 1660 French edition examined for this essay, also part of the Blairs Collection, is unknown,

1 J. R., trans., The Idcea of a Perfect Princesse, in The Life of St. Margaret Queen of Scotland (Paris, 1661); William Leslie, trans., Vita di Santa Margherita regina di Scozia (Life of Saint Margaret queen of Scotland) (Rome: Per Michel'Ercole, 1675); [Alexander Sinclair, trans.,] La idea de una perfecta princesa representada en este compendio de la vida de Santa Margarita reyna de Escocia (The idea of a perfect princess represented in this book of the life of Saint Margaret queen of Scotland), (Madrid, 1679). The French and Italian editions can be found in the University of Aberdeen Library: BCL aa166 and BCL B1574 respectively. 
its quarto size and superior binding decorated with gilt double fillet suggest that it may have been a presentation copy. This speculation is corroborated by the fact that the text was originally intended for a royal audience.

Though we may never answer the question of these books' provenances or readership history, the book does offer many other rich avenues for research. Through its methodology, contents, and paratextual elements, this devotional book can act as a lens into the culture and experience of early modern Scottish Catholics. In this essay, I would like to use what we do know about these books to demonstrate several points about the state of post-Reformation Scottish Catholicism. First, the methodology of the work attests to the strong Jesuit, Counter-Reformation influence in the education and spiritual formation at the Scots colleges established abroad. Second, the book's contents bear witness to the emphasis that Scottish Catholic exiles placed on the maintenance of their national and religious identities while surrounded by other western European traditions. Third, in its defense of Charles II's claim to the throne, the text aligns the Scots colleges with the royalist cause. And finally, beyond its Jesuit, devotional, and royalist considerations, the text served a very practical purpose of soliciting aid and support for the Scots colleges. Reformation Devotion

After the Reformation events of $1559 / 60$, most Catholic priests and monks either fled Scotland or defected to the reformed ministry. ${ }^{2}$ In this situation, and with the death of Archbishop James Beaton (1524-1603), the last Scottish Catholic bishop, in 1603, the maintenance of the old faith in Scotland would have to be a missionary endeavor. Jesuits not only played a large part in maintaining the Catholic faith in post-Reformation Scotland but were also involved in the network of exiled Scots communities on the continent. The Jesuits' first missions to Scotland in the 1560 , 70 s, and 8 os focused on trying to reinstate

2 On the continuity and change between the pre- and post-Reformation clergy see Mark Dilworth, "Monks and Ministers after 1560," Records of the Scottish Church History Society 18 (1974): 201-21; Anthony Ross, O.P., "Reformation and Repression," in Essays on the Scottish Reformation: 1513-1625, ed. David McRoberts (Glasgow: John S. Burns \& Sons, 1962), 371-414; Charles H. Haws, "Continuity and Change: The Clergy of the Diocese of Moray, 1560-74," Northern Scotland 5, no. 1 (1982): 91-98; Gordon Donaldson, "The Parish Clergy and the Reformation," Innes Review 10 (1959): 5-20. 
Catholicism in Scotland via political means, but these were mostly failures. ${ }^{3}$ Upon leaving Scotland, these first missionaries were followed by young Scots who joined the Jesuits with the hopes that when conditions were better, they could return to Scotland as missionary priests. ${ }^{4}$ By the beginning of the seventeenth century the Jesuit strategy had changed from seeking direct political means of effecting religious change to stationing themselves in the houses of nobility and gentry and guiding the intellectual and religious formation of their patrons. ${ }^{5}$ Jesuits bearing books of devotion and controversy was one way in which recusant books made their way into the hands of Scottish Catholics. ${ }^{6}$

The number of missionary priests in Scotland, Jesuit or otherwise, was never high throughout the seventeenth century. After James VI and I (1566-1625; r. [Scotland] 1567-1625 [England] 1603-25) succeeded to the English throne, missionary efforts were concentrated in the south since it was believed that if England were reconverted to Catholicism, Scotland would follow suit. For instance, in 1609 it was reckoned that there were some five hundred priests in England, but only six or seven in Scotland. ${ }^{7}$ Even after the foundation of Pope Gregory XV's (1554-1623; r.1621-23) Congregation of the Propagation of the Faith in 1622, an effort to organize the Catholic Church's missionary efforts, there were only about twenty-five priests in Scotland, many of whom later joined the Jesuits. ${ }^{8}$ It was much harder to survive as a secular missionary priest, that is, a priest not part of a religious order, as they did not enjoy the security of the extensive network that the Jesuits possessed.

3 For a thorough account of the various sixteenth-century Jesuit missions as well as a catalog of those sixteenth-century Scottish Jesuits, see Thomas M. McCoog, "Pray to the Lord of the Harvest': Jesuit Missions to Scotland in the Sixteenth Century," Innes Review 53, no. 2 (2002): 127-88. See also Michael Yellowlees, "So strange a monster as a Jesuite": The Society of Jesus in Sixteenth-century Scotland (Isle of Colonsay: House of Lochar, 2003). For a discussion of Robert Parsons's plans for a Jesuit mission to Scotland in the 1580 , see Thomas M. McCoog, The Society of Jesus in Ireland, Scotland, and England 1541-1588: "Our Way of Proceeding" (Leiden: Brill, 1996).

4 Michael Yellowlees, "Dunkeld and Nicholas de Gouda's Mission to Scotland, 1562," Innes Review 44 (1993): 52-53.

5 Tom McInally, The Sixth Scottish University: The Scots Colleges Abroad, 1575-1799 (Leiden: Brill, 2011), 177 .

6 William James Anderson, "Narratives of the Scottish Reformation," Innes Review 7, no. 1 (1956): 34-35, 37 .

7 Hubert Chadwick, "The Scots College, Douai, 1580-1613," English Historical Review 56, no. 224 (1941): 571-85, here 571 .

8 M. V. Hay, The Blairs Papers 1603-166o (Edinburgh: Sands \& Co., 1929), 247-49. 
The Jesuits were similarly influential in the experience of Scottish Catholics abroad. In the sixteenth and seventeenth centuries, there were four Scots colleges established on the continent, offering an alternative education for Scottish Catholics. It was necessary to found such institutions because at home Catholics were stripped from teaching positions in universities, while other universities required incoming students to make a Protestant confession of faith. ${ }^{9}$ Bishop John Lesley (1527-96) acted as Mary Stuart's (1542-86; r.1542-67) representative in Rome to inquire about setting up a Scottish equivalent of the English and German colleges that had already been founded abroad. The first Scots college was founded in 1580 with Mary Stuart's financial support, and after several moves and temporary closures the college settled in Douai, which was the "centre of Counter-Reformation activity for English-speaking exiles."10 The other colleges opened in Rome in 160o, Paris in 1602, and Madrid in 1627, respectively. ${ }^{11}$ The Scots colleges were not originally founded as seminaries. Rather, as evidenced by the Roman college's papal bull, they were established "to educate young Scots in good morals, piety, sound doctrine and Christian virtues." 12 However, they did eventually become Scotland's default seminaries and produced priests who intended to return to Scotland as missionaries to encourage the faithful and spread the Catholic faith.

The Jesuits administered three of the four Scots colleges, and many of the students who studied at the colleges became Jesuits. Paris remained the only college not run by the Jesuits and its rector, Robert Barclay (1611/12-82), fought hard to keep it free from Jesuit influence. ${ }^{13}$ Like the Jesuit-run English colleges, the life of the Scottish students at Douai, Rome, and Madrid was deeply infused with Jesuit education and spirituality. ${ }^{14}$ The intellectual program at such Jesuit colleges included the study of scripture and correct interpretation of passages,

$9 \quad$ In places like King's College, protected by Queen Mary until 1567, it was not until 1569 that Alexander Anderson, the sub-principal, and several other members of staff were "removed from their posts" and "doctrinally approved replacements were substituted." McInally, Sixth Scottish University, 7 .

$10 \quad$ McInally, Sixth Scottish University, 21.

11 For more on the individual colleges, see: Hubert Chadwick, "The Scots College, Douai, 1580-1613," 571-85; Brian Halloran, Scots College in Paris, 1603-1792 (Edinburgh: John Donald, 1997); The Scots College Rome, 160o-20oo, ed. Raymond McCluskey (Edinburgh: John Donald, 200o); Maurice Taylor, The Scots College in Spain (Valladolid: Andrés Martín, 1971).

12 Mark Dilworth, "Beginnings 1600-1700," in McCluskey, ed., The Scots College Rome, 16oo$2000,20$.

13 Halloran, Scots College in Paris, Chapter 4.

14 Thomas McCoog, "Replant the uprooted trunk of the tree of faith': The Society of Jesus and the Continental Colleges for Religious Exiles," in Insular Christianity: Alternative 
lectures on Thomistic theology, weekly disputations concerning Catholic and Protestant doctrine, as well as practice preaching..$^{15}$ The present Royal Scots College in Salamanca has the only extant library of any of the historic Scots colleges. Its collection includes books representing the major subjects listed above, as well as literature, history, science, etc. in all major European languages. This intentionally well-rounded library collection was meant to support and supplement the students' formal studies. Tom McInally has noted the evidence suggesting that the libraries of the other colleges were similarly extensive and well-stocked. For example, "Douai's library was sufficiently well endowed to gift books" to "augment the library of the Spanish college."16 The extant Spanish library attests to the Jesuit educational influence as a great many of the books in the 1760 catalog were written by Jesuits. ${ }^{17}$

While "students [at the continental Scots colleges] were to be taught in the wider university classes," they also had residential colleges providing for the spiritual needs of the students. ${ }^{18}$ The spiritual life of the students followed a series of Jesuit devotional practices, such as daily examination of conscience, weekly confession, frequent communion, and mental prayer or meditation, described as the time when "the hart and minde is occupied within rather than the tong and lipps without."19 This meditative practice often followed after reading a passage from Scripture or from another devotional text, which would present some object of spiritual knowledge, upon which one was to fix the eyes of one's mind. This technique is derived from St. Ignatius's (c.1491-1556) Spiritual Exercises, a series of led meditations occurring over several weeks, during which the retreat master offers a subject for meditation, such as a Gospel passage. Those participating in the meditation were meant to concentrate upon the subject presented, enter into the scene or subject with all their senses and thoroughly explore all its implications for the devout life. Typically, one would note down any fruits of one's meditations for future reflection. ${ }^{20}$ Students at the Scots colleges would all have been familiar with the Exercises and would have done them at least once, upon entrance to the college. ${ }^{21}$

Models of the Church in Britain and Ireland, c.1570-c.170o, ed. Robert Armstrong and Tadhg Ó hAnnracháin (Manchester: Manchester University Press, 2013), 29.

15 McCoog, "Replant the uprooted trunk of the tree of faith," 28-29.

16 McInally, Sixth Scottish University, 74.

17 Archives of The Royal Scots College Salamanca, Box 23, Item 2.

18 McInally, Sixth Scottish University, 69.

19 McCoog, "Replant the uprooted trunk of the tree of faith," 29.

20 Paul Nelles, "Seeing and Writing: The Art of Observation in the Early Jesuit Missions," Intellectual History Review 20, no. 3 (2010): 317-33.

21 McCoog, "Replant the uprooted trunk of the tree of faith," 41-42. 
This same Ignatian method of meditation from the Spiritual Exercises is echoed in the Jesuit books about Queen Margaret. The first edition, composed in French in 166o by the Jesuits of the Douai college and dedicated to Charles II, has a curious epistle addressed to female readers employing the particular Jesuit rhetoric of meditation. The author begins by offering Queen Margaret, whose name means "pearl" in Greek, as a pearl for the ladies' reflection: "Ladies, I Present you with this Pearl of Queens, not to advance your beauties by its lustre, but to improve the comeliness of your Soules." 22 The author then exhorts his female readers to have

always a strong idea of this holy Queen in your minds [...] take this Pearl that I offer you, dissolve it by frequent reading of this little work; Examine all the particularities, and you will find that they are so many virtues fit for the nourishment of your souls, if you will apply them by a faithful imitation $[. .$.$] you will draw from this reflection, a heavenly vigour. { }^{23}$

Just as an Ignatian meditation would offer some scene or other spiritual object for one's contemplation, so the author of the epistle offers Queen Margaret's life as the object for the women's meditation and contemplation.

In addition to the particular methodology of meditation, the contents of the text also attest to the Counter-Reformation spirituality that the Jesuits propagated at the colleges and help explain why the Scots Jesuits deemed it fitting to use an eleventh-century saint for seventeenth-century devotion. Although the beginning of the book covers Margaret's ancestry, the bulk of the text is concerned with the details of Margaret's pious activities. With the help of Turgot, her spiritual mentor, Margaret is depicted as a great reformer, responsible for reinstating the practice of the full forty days of Lenten fasting, restoring the four ancient bishoprics of the kingdom, building chapels and monasteries, and redecorating those that had fallen into an unacceptable state of ruin. ${ }^{24}$ She exhorts the people of Scotland to receive communion on Easter and other holy days, a practice they had forgone for fear of their unworthiness. ${ }^{25}$ Then, her private acts of piety are covered: her continual practice of fasting, mortification, and prayer. After a short sleep, she would rise at midnight and pray the offices of the most holy Trinity, of the cross, of the blessed Virgin, and of the

\footnotetext{
22 J. R., "The Epistle to the Ladies," in Idcea of a Perfect Princesse.

23 J. R., "Epistle to the Ladies," 30.

24 J. R., "Epistle to the Ladies," 30.

25 J. R., "Epistle to the Ladies," 27-30.
} 
dead, and during the day she would attend up to seven Masses. ${ }^{26}$ She and King Malcolm, whom she converted to a more pious life, would serve a meal to three hundred poor people in the palace with the best food and service. Margaret also personally cared for orphans and tended to the wounds, ailments, and other complaints of the destitute. ${ }^{27}$

Catherine Keene, a modern biographer of Queen Margaret, points out that Margaret's personal program of piety and good works were inspired by an eleventh-century ascetic reform movement popular in continental Europe and emphasized a renewed focus on prayer, fasting, and tending to the poor. ${ }^{28}$ However, Margaret's devout lifestyle and good works are also evocative of Counter-Reformation piety. In response to the Council of Trent (1545-63), a new system of parochial conformity was called for which stressed the importance of the sacraments for the initiation of all Christians into the body of Christ, the church, and the fulfilment of the laity's need for personal holiness and salvation. During the Counter-Reformation, there were voluntary associations of lay people dedicated to encouraging frequent reception of the sacraments and charitable works, such as the Oratory of the Divine Love. ${ }^{29}$ Many new religious orders were devoted to serving the poor and destitute, such as the Ursulines..$^{30}$ Many of the older religious orders, such as the Carmelites and Franciscans, were reformed with a greater ascetic emphasis. ${ }^{31}$

As there are many similarities between Margaret's own religious practices and those emphasized by Counter-Reformation religious orders, it seems likely that the Scots Jesuits viewed Queen Margaret as a fitting example of piety and devotion to offer seventeenth-century women. In order to remind the readers that Margaret's life is not only meant as a devotional tool, but as a guidebook for how to live a holy life, the author of the 1660 French edition interjects the narrative with short, italicized reflections after citing a particular example of her pious behavior. For example, after discussing Margaret and Malcolm's

26 J. R., "Epistle to the Ladies," 39.

27 J. R., "Epistle to the Ladies," 40-42.

28 Catherine Keene, Saint Margaret, Queen of the Scots: A Life in Perspective (New York: Palgrave Macmillan, 2013), 69 .

29 Pierre Janelle, The Catholic Reformation (Milwaukee: The Bruce Publishing Company, 1963), Chapter 6.

$30 \quad$ Keith Randell, The Catholic and Counter Reformations (London: Hodder \& Stoughton, 1990), Chapter 2.

31 Ronnie Po-chia Hsia, The World of Catholic Renewal (Cambridge: Cambridge University Press, 1998), 62; Robert Bireley, The Refashioning of Catholicism, 1450-170o: A Reassessment of the Counter Reformation (London: Macmillan Press Ltd., 1999), 27-28. 
custom of serving food to three hundred poor persons, the author interjects with a short reflection:

Blessed is he who lookes upon the face of the poor, and miserable, who considers their need, to relieve it; who searcheth with the eye of faith, the Son of God in their persons [...] who strongly perswades himself that Jesus Christ resides in the person of the needy, and that he receives their Charity. $^{32}$

These reflections seem to be the author's way of exhorting his female readers to imitate Margaret; in this instance, the author moves from an example of her life to a beatitude-like statement.

\section{St. Margaret's Cult and the Identity of Exiled Scottish Catholics}

There were at least three distinct but related expressions of Scottish Catholic individuals and institutions emphasizing their identity while abroad. The first expression was the development of devotions to various Scottish saints who could inspire a love of faith and country, in spite of everything that had transpired at home. This devotional text about Queen Margaret, written by the Scots Jesuits in Douai and translated by Jesuits at the Rome and Madrid Scots colleges, is only one example of the growing popularity of St. Margaret's cult. The cult of St. Margaret among the exiled Scots communities seems to have begun at the Douai college. It was there that the Scots Jesuits must have come into contact with the manuscript of her life composed between 1100 and 1107 by Turgot. Although Turgot employs some common tropes of hagiography, Catherine Keene has suggested that "the chances that Margaret's Vita adheres more to actual events than hagiolatrous imagination are increased by the fact that it was written shortly after her death, by her spiritual advisor, [and] at the request of her daughter." ${ }^{\prime 33}$ The picture of Margaret presented in the French edition contains all the same anecdotes from Turgot's Vita, following roughly the same order of events, but is supplemented with more contemporary historical sources such as Hector Boece $\left(c .1465^{-1536)}\right.$ and Bishop Lesley's sixteenthcentury histories of Scotland.

The 1675 Italian edition of the devotional book seems to offer a clue of how the Scots Jesuits in Douai might have come into contact with Turgot's

\footnotetext{
32 J. R., "Epistle to the Ladies," 40-41.

33 Keene, Saint Margaret, Queen of the Scots, 4.
} 
manuscript of Margaret's life. The Italian text, translated and edited by William Leslie (1621/2-1707), rector of the Scots college in Rome, aims to be more historical in nature, as it references nearly twice as many historical sources as the French edition. Leslie appears to have had other historiographical ambitions, for he was apparently planning to continue Bishop John Lesley's history of Scotland. Whereas the other three books possess the common title, "The Idea of a Perfect Queen," Leslie goes for a less poetic and more biographical title, "The Life of Saint Margaret Queen of Scotland, collected by different authors and published by Fr. William Leslie." ${ }^{4}$ Instead of an epistle to women, Leslie offers an apology to the reader if his account deviates from the historical truth since he uses several historical authors who do not always agree. Leslie assures his readers that if they are upset by any historical discrepancies in his discourse, that the ancient manuscript of Margaret's life confirms the most important points. He tells us that the Jesuits in Antwerp hold Turgot's manuscript. ${ }^{35}$ The Scots Jesuits in Douai must have known about the manuscript in Antwerp (only about $160 \mathrm{~km}$ away) and used it in the composition of the 1660 French edition of Margaret's life.

We learn in the French edition of the devotional book that upon the eve of the Reformation, the relics of Queen Margaret (her head and hair) were transported to Edinburgh Castle and when they were not safe there, were delivered to the Jesuits in Antwerp in 1597. So, it seems that both the relic and the manuscript of Margaret's life were at one time in the possession of the Jesuits in Antwerp. But in 1645, her relics were moved to the Chapel of the Scots college Douai and it was in that year that Pope Innocent X (1574-1655; r.1644-1655) offered "plenary indulgence to all the faithfull, who having first confes'd, and communicated, would pray before this Relick." ${ }^{36}$ Douai, then, was the center of Margaret's cult until the later seventeenth-century when the same Leslie who translated the work into Italian, petitioned the papacy to add Margaret's feast to the universal calendar of the church, which was granted in 1673 . He also obtained a relic of the saint from Douai and decorated the Roman college's chapel with a painting of her. He then had St. Margaret officially recognized as patron of the Scots colleges and a patron of Scotland as well. ${ }^{37}$

34 Translated from the Italian: Vita di Santa Margherita regina di Scozia raccolta da diversi authori, e data in luce [The life of Saint Margaret queen of Scotland collected by various authors, and published].

35 Leslie, "A chi legge," in Vita di Santa Margherita.

36 J. R., "Epistle to the Ladies," 48.

37 Mark Dilworth, "Jesuits and Jacobites: The cultus of St. Margaret," Innes Review 47, no. 2 (1996): 169-80, here $175^{-77}$. 
In addition to the devotions to St. Margaret at the Scots colleges, the Scottish Benedictine monasteries in Bavaria, or the Schöttenkloster, also propagated saints' cults. For instance, the monks in Wurzburg claimed St. Macarius (1139-53) as their founder and first abbot and in $1614 / 5$ had his relics translated to the monastery after they had been recently discovered. ${ }^{38} \mathrm{~A}$ few years later in 1618, a relic of Merolilan, an eighth-century saint, was transferred to the Scots college in Rome. That same year Patrick Anderson (1574/5-1624), a Scottish Jesuit, was given one of Merolilan's relics. Anderson developed an interest in Scottish hagiography and apparently compiled a compendium of Scottish saints-Menologium sanctorum Regni Scotiae (Compendium of the saints of the Kingdom of Scotland), now lost. Stephen Holmes attributes the Scottish exiles' interest in and attention to Scottish saints as motivated by "a desire for holy martyrs as patrons and models for those preparing for the difficult Scottish mission" especially after the martyrdom of the Scottish Jesuit, John Ogilvie (1578/9-1615), in Glasgow in $1615 \cdot{ }^{39}$

A second expression of the Scottish Catholic exiles' emphasis of their religious and Scottish identities manifested itself in the acceptance policies of the Scots colleges and the Schöttenkloster. These institutions only admitted native-born Scots or those who had been born abroad to Scottish parents. ${ }^{40}$ By insisting on such strict acceptance policies, Tom McInally has claimed that these institutions "were able to retain their distinctive Scottish-ness and represented a Scottish Catholic Church, albeit, one in exile." ${ }^{\text {11 }}$ Although the papacy attempted several times to combine the English and Scots colleges, the Scots viewed such measures as threats to the identity they had worked so hard to foster in their national institutions, and the last attempt to do this in 1708 was successfully resisted. ${ }^{42}$

The development of the "Scottish Legend" is a third expression of the Scots' cultivation of their identity while in exile. Macarius's story and the miracles attributed to him, along with the stories of other ancient and medieval Scottish saints, were used in historical and devotional works by Scottish Catholic exiles who wished to glorify Scotland's Catholic past. These works multiplied in the late sixteenth and early seventeenth centuries and included works such

\footnotetext{
38 Mark Dilworth, The Scots in Franconia: A Century of Monastic Life (Edinburgh: Scottish Academic Press, 1974), 217.

39 Stephen Holmes, "The Relics of St Merolilanus and Scotland," Scottish Historical Review 91, no. 1 (2012): 150-58, here 153 .

$40 \quad$ Halloran, Scots College in Paris, 13; McInally, Sixth Scottish University, 165.

41 McInally, Sixth Scottish University, 165.

42 McInally, Sixth Scottish University, 164.
} 
as Bishop Lesley's De origine, moribus, ac rebus gestis Scotiae libri decem (On the origin, customs, and achievements of the Scots in ten books, 1578), George Thomson's De antiquitate religionis apud Scotos (On the antiquity of religion among the Scots, 1594), Thomas Dempster's Historia ecclesiastica gentis Scotorum (The ecclesiastical history of the Scottish people, 1627), and David Camerarius's De Scotorum fortitudine (On the strength of the Scots, 1631). These works attempted to give a historical analysis of Scotland's past, especially with regard to religion, claiming "thirteen and a half centuries of heresy-free Christian history before 1560 , during which Scotland was a [...] nursery of saints and scholars, who [...] took the light of the gospel to most of western Europe."43 These historical works were in response to the Protestant histories composed at the same time, for example, John Knox's The Historie of the Reformation of the Church of Scotland $(1587,1644)$ and George Buchanan's (1506-1582) Rerum Scoticarum historia (A history of Scotland, 1582), which offered a much different vision of Scotland's past. Whereas the Scottish Catholic writers, especially the later ones, as Thomas Law pointed out, wrote nostalgically about the Catholic past of their country forgetting about any corruption, ${ }^{44}$ the Protestant authors related "the great Work of purging the Church from the Superstitions and Idolatry, and freeing both Church and State from the Tyranny and Slavery of Popery." 45

This trend of emphasizing the Scottishness of the Catholic faith, especially within a devotional context, preceded the Reformation. The founder of the University of Aberdeen, Bishop William Elphinstone (1431-1514), and his team of reforming liturgists, created the 1509 Aberdeen Breviary, a replacement for the English Sarum breviary. Although Elphinstone had worked on compiling a martyrology of Aberdeen saints, the saints chosen for the breviary were selected on a national basis. ${ }^{46}$ Unlike older chronicles or histories, the Aberdeen Breviary offered "a systematic survey of Scottish saints which fully cut across regional [and] ecclesiastical boundaries," and was meant to help the Scots "rediscover their past and so to love the nation's differing cultures and

\footnotetext{
43 Dilworth, The Scots in Franconia, 214

44 Catholic Tractates of the Sixteenth Century: 1573-160o, ed. Thomas G. Law (Edinburgh: William Blackwood and Sons, 1901), xxviii-xxx.

45 John Knox, "To the Reader," in The Historie of the Reformation of the Church of Scotland: Containing five Bookes; Together with Some Treatises Conducing to the Historie (Edinburgh: Robert Bryson, 1644).

46 Leslie J. Macfarlane, William Elphinstone and the Kingdom of Scotland 1431-1514: The Struggle for Order (Aberdeen: Aberdeen University Press, 1985), 237.
} 
traditions." ${ }^{\text {77 }}$ Between the selection of saints and James IV's (1473-1513; r.14881513) support, the breviary propagated the idea that all Scots belonged to an imagined community and was an attempt to cultivate a native devotion and "to create a national liturgy for Scotland." 48 In the same way that Elphinstone's Breviary used Scottish saints to build community throughout Scotland, devotional literature and practices of the Scots colleges, the acceptance policies of the Scots colleges and the Schöttenkloster, and the historical writings composed by exiled Scottish Catholics were all attempts to solidify and maintain a strong Scottish and Catholic identity while in exile among other western European traditions.

\section{St. Margaret and the Royalist Cause}

In addition to their Jesuit influence and their participation in the trend of emphasizing and encouraging the Scottish identity of their Catholicism while abroad, these books also served more pragmatic purposes, as is evidenced by their paratextual elements. First, the dedicatory epistle to Charles II found in the French edition of 1660 aligned the Scots college with the royalist cause. Catholics hoped the restoration of the Stuarts would bring a relaxation of the penal laws. Celebrating Charles's glorious restoration, the author of the epistle claims that the recent sufferings of the Stuart household were part of the plan of divine providence, claiming that exposure to the greatest storms only served to strengthen the Stuart empire. ${ }^{49}$ After offering some flattering remarks on the resilience of Charles's spirit, his courage, and his virtues as a ruler, the author aligns the Douai Scots college with the Stuart line, claiming that this house [i.e. the college] "has the honour of belonging to the house of Stuart not only because we are the subjects of your majesty, but also because it owes its foundations to the great Mary Stuart" who had been the catalyst behind its foundation in 1580.50

\footnotetext{
47 Thomas Turpie, "Scottish Saints' Cults and Pilgrimage from the Black Death to the Reformation, c.1349-156o" (PhD diss., Edinburgh University, 2011), 32; Macfarlane, William Elphinstone, 244.

48 Jenny Wormald, Court, Kirk and Community: Scotland, 1470-1625 (London: Edward Arnold Ltd., 1981), 82; Roger Mason, "Renaissance and Reformation: The Sixteenth Century," in Scotland: A History, ed. Jenny Wormald (Oxford, 2005), 95.

49 Scots College Douai, "Epistre 'Au tres-havt, et tres-pvissant monarqve le roy de la Grande Bretagne \&c," in L'Idée de une reine parfaite en la vie de S. Margverite reine d'Escosse (Douai: Baltazar Bellere, 1660).

5o Scots College Douai, "Epistre 'Au tres-havt, et tres-pvissant monarqve."
} 
The connection between the Scots colleges and the royalist cause preceded the Restoration. Tom McInally has pointed out that in the 1640 s, a number of students from the Scots colleges suspended their studies to fight in Charles's army, and that "college alumni who had taken up military careers on mainland Europe returned to Britain to fight for the king."51 It was also during this decade that Paris experienced its greatest influx of Scottish expatriates as "royalist refugees from each of the three British kingdoms flooded into the city." 52 In addition to providing soldiers for the royalist cause, the Scots college in Paris acted as a refuge for young royalist officers, some of whom were not Scottish themselves.

Although the English edition of 1661 neither makes explicit mention of the Scots colleges nor retains the epistle to Charles II, it contains a postscript "clearly proving, against the false pretences of the Phanaticks, his Majesties just and right Title to the Crown of England, and to his other Dominions." In the postscript, the translator claims that his translation was intended for two purposes: firstly, to "raise piety in our hearts to God" and secondly, to "excite our loyalty to the King." ${ }^{53}$ The first purpose is obtained by reading and reflecting upon the exemplary life of St. Margaret, while the second is achieved by proving Charles's right to the throne by virtue of being "lineally descended from St. Margaret, the true heir of the Saxon Monarchy." ${ }^{\prime 4}$ He uses both Bishop Lesley's and Buchanan's histories, as well as Richard Baxter's (1615-1691) Chronicle of the Kings of England (1645), Walter Bower's (1385-1449) Scotichronicon (Chronicle of the Scots, 1447) and Hector Boece's Historia gentis Scotorum (History of the Scottish people, 1527) to prove Charles's descent from Margaret and his rightful claim to the crown of England, Ireland, and Wales.

The dedicatory epistle in the English edition, signed by an unidentified "J. R.," also serves to reinforce the connection between Catholic recusants and the royalist cause. J. R. claims it is fitting to dedicate the book to the countess of Arundell and Surrey (c.1609-76) "whose perfections so much resemble [Margaret's]; having so neer Allyance to the Royal bloud, as being a Daughter of the most illustrious house of Lenox, the most antient branch of the Royal family of the Stuarts. ${ }^{\prime 5}$ Although not much has been written about Cecily née Compton, she was the wife of Henry Arundell, third Baron of Arundell of Wardour (c.1608-94), the Arundells being "one of the most prominent Catholic families

\footnotetext{
$5^{1} \quad$ McInally, Sixth Scottish University, 39-40.

52 McInally, Sixth Scottish University, 40.

53 J. R., "Epistle to the Ladies," 91.

54 J. R., "Epistle to the Ladies," 92.

55 J. R., "The Epistle Dedicatory," in Idcea of a Perfect Princesse.
} 
in post-Reformation England." ${ }^{56}$ Henry himself was a royalist officer and politician, dedicated to fighting for the rights of recusant Catholics. He fought against the parliamentarian forces in 1643 to regain his family seat at Wardour Castle in Wiltshire, and solicited Cromwell to protect Catholics, and after the Restoration was active in Parliament. ${ }^{57}$ At the end of the dedication to Cecily, the translator points out that she is blessed to have witnessed the Stuarts, "after a long and sad Eclypse, again shining in the Orb of Majesty" and to "have seen your own Children restored [...] to the Title and Dignity of their Noble Ancestors, the Dukes of Norfolk, their ancient and just Honours." ${ }^{58}$ Thus the Arundells seem to have had several reasons for supporting Charles's restoration, from regaining their family seat, to the hoped for relaxation of penal laws, to the restoration of titles to their children.

\section{5 St. Margaret and the Appeal for Alms}

In addition to the French and English texts serving to reinforce the link between the Scots colleges and the royalist cause, the epistles of the Italian and Spanish editions had an equally practical purpose. These later epistles from 1675 and 1679 were used to solicit support and aid for the Scots colleges. Publishing appeals for alms was a practice across the English, Scottish, and Irish Jesuit continental colleges. Allison and Rogers's bibliography of literature from the English Counter-Reformation lists many publications from the continental colleges that were specifically written and printed as appeals for alms. Such tracts and books came in various forms; some were devotional in nature, like the books about Queen Margaret, some were historical in nature, like the Douai Scots College's De antiquitate christianae religionis apud Scotos (On the antiquity of the Christian religion among the Scots, 1594) and the Madrid English College's Los motivos que ay para favorecer los seminarios de ingleses... (Reasons for supporting the English seminaries, 1632), while others were appeals made directly from the students, such as the Salamanca Irish College's Razonamiento

${ }_{5} 6$ Peter Sherlock, "Arundell, Henry, Third Baron Arundell of Wardour (bap. 1608, d. 1694)," in $O D N B$, https://doi.org/10.1093/ref:odnb/716 (accessed October 27, 2019).

57 Michael C. Questier, Catholicism and Community in Early Modern England:Politics, Aristocratic Patronage and Religion, c.1550-1640 (Cambridge: Cambridge University Press, 2006), $507-8$.

$5^{8} \quad$ J. R., "Epistle Dedicatory." 
que vn colegial del Colegio de los Irlandeses... (Rationale of a student from the Irish College, 1608$).{ }^{59}$

The dedicatory epistle in The Idcea of a Perfect Princesse to the countess of Arundell seems to have become a template for the dedications in the Italian and Spanish editions. Like the English edition, the Italian edition contains a very flattering dedication to an influential Catholic woman. Leslie chose to dedicate his translation to La Signora D. Olimpia Aldobrandina Pamfilia principessa di Rossano. Olimpia Pamfilia (1623-81), known as the princess of Rossano, was deeply involved in the cultural scene in Rome, attending and hosting musical and theatrical evenings for the pleasure of cardinals, noble ladies, and gentlemen. ${ }^{60}$ The author of the Italian epistle, presumably Leslie, seems to have taken a cue from the English epistle, which compared the Countess Arundell's virtues to those of Queen Margaret. In a like manner, Leslie claims it is fitting to present his book to Olimpia "in the guise of a shell caught in your sea," which "encloses a precious pearl [i.e. St. Margaret], in which, like a mirror, represents the rarest quality and virtues of your excellency," again making reference to the etymological meaning of Margaret's name ${ }^{61}$ Like the French edition, the Italian and Spanish editions do reference the respective Scots colleges. Leslie claims that the Roman Scots college belongs to Olimpia for two reasons: firstly, that her uncle, Pope Clement VIII (1536-1605; r.1592-1605), was responsible for the college's foundation; and secondly, that she has played a significant role in conserving, protecting, and providing for the college in its greatest need. ${ }^{62}$ Although the epistle may not be explicitly asking for alms like the Irish and English college publications mentioned above, the epistle and devotional book is meant as a way of thanking Olimpia, out of the college's great debt to her, for her past dedication to the college, and as an encouragement to continue her support of the college, as it prays that heaven will shower her with many celestial gifts. ${ }^{63}$

Like the Italian edition, the Spanish edition was also dedicated to an influential Catholic woman. The Spanish edition was translated $c .1679$ by Alexander

59 A. R. Allison and D. M. Rogers, The Contemporary Printed Literature of the English Counter-Reformation between 1558-1640, vol. 1 (Aldershot: Scholar Press, 1989), 165 (\#1251); 105 $(\# 755) ; 134(\# 962)$.

6o Valeria de Lucca, "Strategies of Women Patrons of Music and Theatre in Rome: Maria Mancini Colonna, Queen Christian of Sweden, and Women of Their Circles," Renaissance Studies 25, no. 3 (2010): 374-92, here 384-85.

61 Leslie, "All'Ill.ma et Ecc.ma Sig.ra padrona colendissima la Signora D. Olimpia Aldobrandina Pamfilia principessa di Rossano \&c.," in Vita di Santa Margherita.

62 Leslie, "All'Ill.ma et Ecc.ma Sig.ra padrona colendissima."

63 Leslie, "All'Ill.ma et Ecc.ma Sig.ra padrona colendissima." 
Sinclair (or Scott), a native of Aberdeen and a convert to Catholicism. ${ }^{64}$ Sinclair studied in Douai, Madrid and Rome, after which he joined the Jesuits and taught at the Madrid Scots college. ${ }^{65} \mathrm{He}$ dedicated his translation to "La Excelentísima Señora Doña María de Guadalupe Lancastre y Cárdenas." María Guadalupe de Lancastre (1630-1715) was born in Portugal to parents of noble lineage. She spent most of her time in Madrid, where she relocated in 166o. In 1673, she married D. Manuel Ponce de León (1633-93), sixth duke of Arcos. ${ }^{66}$ Although little recognized today, María was a well-known figure of her day, both in Portugal and Spain, as well as in Mexico. Specifically, she was distinguished for her intellectual, cultural, and pious activities. She was learned in many languages, history, philosophy, and theology, among other subjects. She was one of only a few women of her rank and status who possessed the skill and talent of painting. María's pious activities included supporting a convent that had been protected by her ancestors, as well as corresponding with missionaries and supporting their missions to foreign lands. In a funeral oration composed about her, María is depicted as spending most of her time either reading or praying, between her library and oratory. ${ }^{67}$ Her impressive library of over four thousand volumes attests to both her intellectual and religious inclinations. The surviving manuscript catalog lists dictionaries and grammars for many different languages and theological, moral, apologetic, and devotional

64 The title page indicates that the edition was translated using both the French and English editions: "Sacado de sv vida, escrita en frances, y ingles; por vn padre de la Compania de Iesvs del Colegio Escoces en Madrid." Sinclair, title page in La idea de una perfecta princesa.

65 Maurice Taylor, Scots College in Spain, 306. Taylor mentions that Sinclair was "professor of Philosophy and Belles Lettres, Scots College, Madrid, c.1677-79 (for five years?); author of Principium feminarum exemplar, id est, vita Sanctae Margaritae, Scotorum Reginae (A prime example for women, that is, the life of Saint Margaret, Queen of the Scots, Madrid, 1679) and of verse-play on life of St. Hermenegild, martyr, performed by his pupils in Rhetoric on October 18, 1668; died in Madrid, April 20/22, 1679." It does not seem that the book Taylor refers to survives. It is possible that he could mean Sinclair's translation of L'Idée d'une reine parfaite. Either way, 1679 seems to be a suitable date for his translation since María Guadalupe inherited titles from her uncle and brother who died without succession in 1673 and 74, respectively. The title that appears in Sinclair's dedication, is spelled "Duquesa de Abeyro," the old Spanish spelling for "Duchess of Aviero," which although was inherited in 1673, was not officially recognized until 1679. Luis de Moura Sobral, "María Guadalupe de Lencastre (1630-1715): Cuadros, libros y aficiones artísticas de una duquesa ibérica," (Paintings, books and artistic hobbies of an iberian duchess) Quintana 8 (2009): 61-73, here 63 .

66 Sobral, "María Guadalupe De Lencastre," 63.

67 Sobral, "María Guadalupe De Lencastre," 67. 
texts. ${ }^{68}$ From these biographical details alone, it is clear why Sinclair might have thought it appropriate to dedicate this devotional book to such a woman, a woman who resembled Margaret's good example in her public role in society.

The first two-thirds of the dedication to María Guadalupe is a direct translation from the English dedication to the countess of Arundell, comparing the respective ladies' virtues to those of Queen Margaret. Like the French and English editions, which claim that Margaret's blood runs in the veins of Charles II and the countess of Arundell, the Spanish dedication makes the same claim about María Guadalupe. As her name suggests, María is descended from the Portuguese house of Lancaster through its descent from King João II (1455$1495 ;$ r.1481-95). After the murder of Henry VI (1421-71; r.1422-61 and 1470-71), the Lancastrian descent continued in Spain and Portugal through the marriage of Philippa of Lancaster (1360-1415; r.1387-1415) to King João I (1357-1433; r.1385-1433) ${ }^{69}$ Like J. R.'s claims about the countess of Arundell, Alexander Sinclair saw it fitting to dedicate the book about Queen Margaret to María Guadalupe not only for the similarity of her virtues to Margaret's, but also because María was lineally descended, albeit distantly, from Margaret.

María Guadalupe seems to have had a relationship to the Scots college in Madrid similar to that of Olimpia Pamfilia's to the Roman Scots college, that is, one of patronage. Like the Italian edition, which offers the book to Olimpia as a shell containing a precious pearl, Sinclair also draws on the shell and pearl imagery but elaborates it with historical and mythological references, going well beyond the original allusion to the meaning of Margaret's name. Of all the dedicatory epistles, Sinclair's is the most imaginative, perhaps appealing to María's literary and artistic proclivities. In the first instance of offering María Guadalupe the book as a shell, Sinclair claims to present a shell similar to the one given to King Francis I of France (1494-1547; r.1515-47), perhaps suggesting the priceless value of a devotional book for the soul. The miraculous story of an oyster shell presented to Francis I is recounted by Julius Caesar Scaliger (1484-1558) in his 1557 Exercitationes (Exercises). Scaliger relates that this small oyster shell contained within it a little bird "almost finished with Pinions, Feet, and the Bill sticking to the Extremities of the Shell," which some men believed to be a transformation of the oyster. ${ }^{70}$ Referencing the transformation, Sinclair then draws a parallel between the nature of this small bird and that of the mythological phoenix, which is known for its transformation and

68 Sobral, "María Guadalupe De Lencastre," 68.

69 Anthony Goodman, "Philippa (1360-1415)," ODNB, http://www.oxforddnb.com/view/ article/22111 (September 2, 2019).

Richard Burthogge, Of the Soul of the World; and of Particular Souls (London, 1669), 33. 
rebirth through fire. In the same way, by this metamorphosis, the bird will be transformed into a jewel. Sinclair claims that it is the fecundity of the shell that makes the transformation possible, and that this devotional book possesses the same potential fecundity: in "this book there are to be discovered as many jewels, as our precious Margaret contained virtues." ${ }^{71}$ At the end of the epistle, Sinclair again offers the book as a shell to María Guadalupe, this time as a "concha peregrina," that is, a pilgrim shell. ${ }^{72}$ Although scallop shells may contain pearls, their occurrence is quite rare. Perhaps Sinclair is comparing the rarity of a truly virtuous person like Margaret to a precious conch pearl. However, the pilgrim shell also likely refers to the scallop shell associated with the famous pilgrimage walk to Santiago de Compostela. Pilgrims would attach a pilgrim shell to themselves at the beginning of their pilgrimage as a sign of their destination. Pilgrimages to holy sites were viewed as a foreshadowing of man's pilgrimage through life to his ultimate heavenly destination. In a similar way, perhaps Sinclair meant for the devotional book to be a guide for María Guadalupe along her earthly pilgrimage. Either way, the book seems to be meant as a gift to María Guadalupe as "a demonstration of the affection of the Scottish College," likely in response to some aid or support she had given to the college. ${ }^{73}$ Though it is unclear whether the countess of Arundell was connected with the Scots colleges, it is clear that the Italian and Spanish texts were dedicated to two local women, Olimpia Pamfilia and María Guadalupe, for their support of the respective Scots colleges.

\section{6}

\section{Conclusion}

After the Reformation, Scottish Catholic exiles, living in small communities across continental Europe, struggled to maintain a sense of unity because their own nation was hostile to their faith. Those convinced of God's calling to convert their country, such as Bishop Lesley, established the Scots colleges, which became both a refuge for exiled religious persons and other devout patrons of the faith, as well as a fertile ground for the royalist cause and for training the next generation of missionary priests. As the Margaret devotional text

\footnotetext{
71 [Sinclair], "A La Excelentísima Señora Doña María de Guadalupe Lancastre y Cárdenas...," in Idea de una perfecta princesa.

72 [Sinclair], "A La Excelentísima Señora."

73 [Sinclair], “A La Excelentísima Señora."
} 
attests, the Scots colleges and other communities of exiled faith relied on devotional books and practices that invoked important Scottish Catholic figures. Such texts and practices helped Scottish Catholics maintain a sense of identity among other European traditions while bolstering their courage to participate in political and religious missions in their homeland. 